\title{
Response of the headcut erosion process to flow energy variation in the loess gully region of China
}

\author{
Qianhua Shi ${ }^{1}$, Wenlong Wang ${ }^{1}$, Mingming Guo ${ }^{1}$, Zhuoxin Chen ${ }^{1}$, Lanqian Feng ${ }^{2}$, and Man \\ Zhao $^{1}$ \\ ${ }^{1}$ Northwest A\&F University \\ ${ }^{2}$ Institute of Soil and Water Conservation Chinese Academy of Sciences and Ministry of \\ Water Resources
}

June 23, 2020

\begin{abstract}
Headcut erosion is usually associated with the consumption and transformation of flow energy that occurs when runoff is used to transport sediment. Therefore, flow energy variations in the headcut erosion process are critical in the loess gully region of the Loess Plateau. The aim of this study was to clarify the effects of the flow discharge and slope gradient on flow energy and the response of the headcut erosion process in the gully region of the Loess Plateau. This study examined the headcut erosion process using slope gradients ranging from $1^{\circ}$ to $7^{\circ}$ in the upstream catchment area and downstream gully bed and inflow discharges ranging from 3.6 to $7.2 \mathrm{~m} 3 \cdot \mathrm{h}-1$. The results showed that the slope gradient has a significant impact on the potential energy in the upstream catchment area; thus, changes in the slope gradients produced changes in the sediment yield. Moreover, the flow discharge significantly influenced not only the potential energy but also the kinetic energy in the upstream catchment area and downstream gully bed. The kinetic energy at the downstream gully bed was $0.03^{\sim} 0.16 \mathrm{~J} \cdot \mathrm{s}-1$ lower than that in the upstream catchment area due to the flow drop at the gully head. Greater energy consumption occurred at the gully head than in the upstream catchment area and downstream gully bed, and the gully head contribution to the flow energy consumption was $44.30 \sim 64.29 \%$, which increased with increasing flow discharge and decreasing slope gradient. The influence of the slope gradient on the sediment yield was more significant than that of the flow discharge, and a nonlinear regression equation was developed to estimate sediment the yield. The flow energy consumption was significantly correlated with the sediment yield. These findings could improve our understanding of the flow energy characteristics and headcut evolution process during headcut erosion.
\end{abstract}

\section{Hosted file}

Response of the headcut erosion process to flow energy variation in the loess gully region of China.doc available at https://authorea.com/users/336181/articles/461971-response-of-the-headcuterosion-process-to-flow-energy-variation-in-the-loess-gully-region-of-china

\section{Hosted file}

Figures.docx available at https://authorea.com/users/336181/articles/461971-response-of-theheadcut-erosion-process-to-flow-energy-variation-in-the-loess-gully-region-of-china 